\title{
A Moderate Translation Alternative to the Baja British Columbia Hypothesis
}

Robert F. Butler and G eorge E. G ehrels, D epartment of $\mathrm{Geosciences,}$ U niversity of Arizona, Tucson, AZ 85721, USA,butler@geo.arizona.edu

Kenneth P. Kodama, D epartment of Earth and Environmental Sciences, Lehigh U niversity, Bethlehem, PA 180153188,USA

\section{ABSTRACT}

The Baja British Columbia (Baja B.C.) hypothesis derives primarily from observed discordant paleomagnetic directions of Insular and Intermontane terranes interpreted to indicate post-mid-Cretaceous northward transport by up to $4000 \mathrm{~km}$ with respect to the continental interior. Recent paleomagnetic results from near Prince Rupert, British Columbia, document that discordant directions in plutonic rocks of this area are primarily due to local deformation rather than transport from a Cretaceous location along the southwest margin of North America. Expanded paleomagnetic studies of Cretaceous rocks at Duke Island and MacColl Ridge, Alaska, have led to much smaller estimates of latitudinal motion for Insular terranes than previously concluded. Recognition of likely chemical remagnetization of Cretaceous sequences in the Tyaughton and Methow basins, along with effects of compaction shallowing on marine sediments of the Nanaimo Group, indicate that paleomagnetic data from these rocks may not require the magnitude of northward transport suggested by the Baja B.C. paleogeography. Instead, the paleomagnetic observations are consistent with a Cretaceous paleogeography that limits post-midCretaceous northward motion to $\sim 1000$ $\mathrm{km}$. The resulting paleogeography has the appealing feature of an Andean-like, continuous subduction-related magmatic arc along the Cordilleran margin during Cretaceous time.

\section{INTRO DUCTIO N}

One may quibble over the details, but the general picture on paleomagnetism is sufficiently compelling that it is much more reasonable to accept it than to disregard it.

- H.H. Hess, 1962

It is clear that much of the North American Cordillera is composed of terranes of oceanic affinity that were added to and shuffled along the continental margin during Mesozoic and Cenozoic time (Coney et al., 1980). Paleomagnetism contributed to the realization that some terranes experienced large-scale latitudinal motion prior to or following accretion to the continental margin (Hillhouse, 1977). But Cordilleran geologists now find themselves struggling with the Baja British Columbia (Baja B.C.) hypothesis, which many perceive as a fundamental conflict between paleomagnetic data and geologic observations. We view the controversy as growing pains in attempts to decipher the tectonic evolution of an orogen where supracrustal rocks have largely been removed and those remaining are complexly deformed. The remark by Hess (1962) reminds us of the apparent conflict between paleomagnetism and conventional geological wisdom regarding continental drift (Irving, 1988). In his celebrated article, Hess laid out concepts of plate tectonics resolving that apparent conflict. A more recent example of perceived conflict between paleomagnetism and geology resolved to the benefit of both disciplines is vertical-axis rotations of parts of the Cordilleran margin (Kamerling and
Luyendyk, 1979; Beck et al., 1986). This history suggests that apparent conflicts between paleomagnetism and geology can lead to significant insights that neither discipline alone could have delivered.

The Baja B.C. controversy is focused on the magnitude of post-midCretaceous northward transport of segments of the North American Cordillera. Did southeast Alaska, western British Columbia, and the North Cascades experience northward transport during the last 100 m.y., limited to $500-1000 \mathrm{~km}$, as interpreted from the geologic record of inboard strike-slip faults (Price and Charmichael, 1986)? Or was this region, in midCretaceous time, situated adjacent to the continental margin in the position now occupied by Baja California (Cowan et al., 1997)? The Baja B.C. hypothesis remains controversial and was the focus of a recent Penrose Conference (Mahoney et al., 2000). The primary motivation for the Baja B.C. hypothesis comes from discordant paleomagnetic directions interpreted to favor post-midCretaceous northward transport up to 4000 km (Beck, 1980; Irving et al., 1996; Ward et al., 1997). However, the magnitudes of northward transport interpreted from paleomagnetic data in Cretaceous rocks range from $\sim 500 \mathrm{~km}$ (Vandall, 1993) to $\sim 4000 \mathrm{~km}$ (Panuska, 1985). So the paleomagnetic data do not provide a unified and simple signal to interpret. In addition to northward transport, part of the paleomagnetic discordance must result from geologic deformations such as faulting or folding of crustal panels. But between transport and structural disturbance, which is the signal and which is the noise?

In this paper, we offer ideas and observations that permit understanding of paleomagnetic observations from Insular and Intermontane terranes (Fig. 1) 
with much less northward transport than suggested by the Baja B.C. model. Our approach is conservative and we are sometimes pushing the confidence limits on paleomagnetic observations toward lower displacement estimates. The resulting Cretaceous paleogeography avoids many of the geological conflicts of the Baja B.C. hypothesis but still requires $\sim 1000 \mathrm{~km}$ post-mid-Cretaceous northward motion for large segments of the North American Cordillera.

\section{CHANGES IN LATITUDE OR CHAN GES IN ATTITU DE?}

The majority of discordant paleomagnetic results have been obtained from intrusive igneous rocks for which interpretation is complicated by lack of control on paleohorizontal at the time of magnetization. The general pattern of shallow inclinations and clockwise-deflected declinations observed in the Cretaceous plutonic rocks can be explained either by northward transport coupled with clockwise vertical-axis rotation or by systematic northeast-side-up tilt during uplift. A "translation versus tilt" controversy has ensued (Butler et al., 1989; Ague and Brandon, 1997). A central issue is the plausibility of plutonic rocks experiencing tilt of sufficient magnitude and correct geometry to explain the discordant paleomagnetic directions.

A bias towards shallower inclinations results from the steep expected direction in Cretaceous time when the paleomagnetic pole was located in northern Alaska, at its closest approach to the Cordillera. The steep expected direction results in high probability that a deflection will result in a shallower rather than steeper direction (Fig. 2A). Because the expected declination is aligned with the structural grain of the Insular terranes and Coast Mountains, tilting of crustal panels about axes subparallel to the structural grain will always produce shallower observed inclinations.

End-member translation and tilt interpretations of the discordant paleomagnetic direction from the Spuzzum pluton of southem British Columbia are illustrated in Figure 2. On the assumption that present horizontal approximates paleohorizontal, the $17^{\circ}$

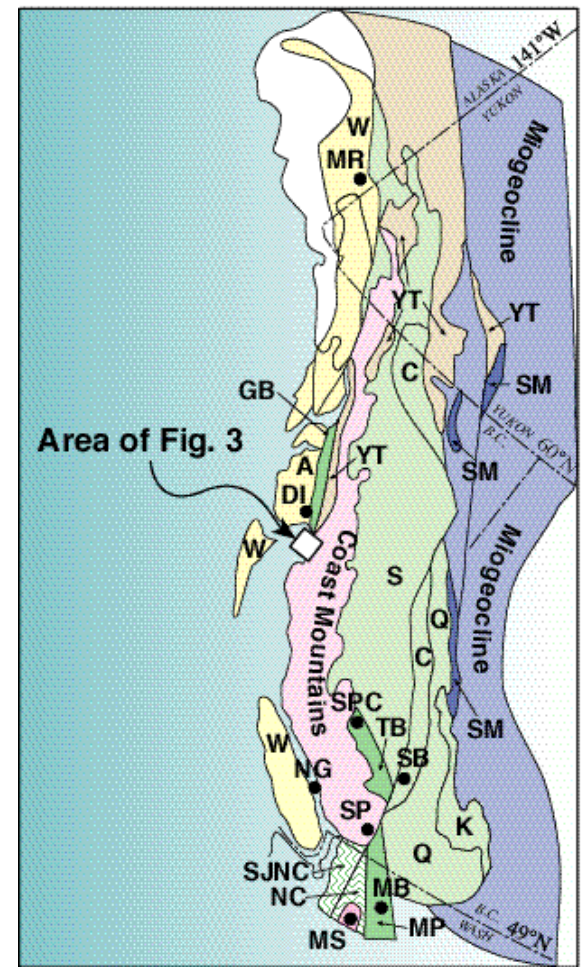

Figure 1. Generalized geological map of Coast M ountains and terranes of northern Cordillera. Prince Rupert area is outlined by box. Adapted from Gehrels and Kapp (1998). Geologic terranes: A-Alexander; C-Cache Creek; K-Kootenay; M PMethow-Pasayten basins; NC-high grade rocks of N orth Cascades; Q-Q uesnel; SStikine; SJN C - San Juan-N orth Cascades thrust belt; SM - Slide M ountain; TBTyaughton Basin; YT-Yukon-Tanana. Paleomagnetic studies: DI-Duke Island; MB-M ethow Basin; M R-M acColl Ridge; MS-M ount Stuart; N G - N anaimo G roup; $\mathrm{SB}$ - Spences Bridge; SP-Spuzzum pluton; SPC-Silverquick-Powell Creek.

flattening of observed inclination indicates $\sim 2500 \mathrm{~km}$ of northward motion while the discordant declination indicates $58^{\circ}$ of clockwise vertical-axis rotation (Fig. 2B). Alternatively, the expected direction can be deflected to the observed direction by $\sim 30^{\circ}$

northeast-side-up tilt of the pluton about a horizontal axis with azimuth $\approx 330^{\circ}$ (Fig. 2C). This northwest-southeast axis is subparallel to the structural grain of the Coast Mountains and consistent with structures that could tilt panels of crust. Barometry of metamorphic assemblages surrounding the Spuzzum pluton indicates that this panel of crust tilted northeast-side-up by $33^{\circ}$ about an axis with azimuth of $332^{\circ}$ (Brown and Burmester, 1991).

\section{EXAMPLES OF TILTIN G AN D FO LDING FROM THE PRIN CE RU PERT AREA}

The Quottoon plutonic complex was emplaced into eastern parts of the Coast shear zone (Fig. 3), considered by some workers to have accommodated $\sim 2000$ $\mathrm{km}$ of strike-slip motion between the Insular terranes and Intermontane terranes (Hollister and Andronicos, 1997). Paleomagnetic data were obtained from more than 200 sites distributed from the Skeena River to Willard Inlet. $\mathrm{U}-\mathrm{Pb}$ crystallization ages range from 72.3 to $55.5 \mathrm{Ma}$ (Klepeis et al., 1998). K-Ar hornblende dates indicate Eocene cooling and magnetization after the proposed northward motion of Baja B.C. However, locally, the Quottoon plutonic complex yields paleomagnetic directions that are shallow and rotated clockwise, similar to plutons within Baja B.C. to the west. Eocene extension of the Coast Mountains tilted crustal panels that are bounded by northwest striking east-side-down normal faults and northeast-striking transfer faults (Fig. 3; Butler et al., 2001b). Based on a tilting domino model, $\sim 30 \%$ extension can produce the $40^{\circ}$ maximum tilts.

We collected paleomagnetic sites along a northeast-southwest transect across the northern part of the Ecstall pluton (Butler et al., 2000).

Geobarometry and U-Pb analyses indicate $91 \mathrm{Ma}$ crystallization at a depth of $\sim 25 \mathrm{~km} .{ }^{40} \mathrm{Ar} /{ }^{39} \mathrm{Ar}$ dates on hornblende from the western margin indicate cooling and magnetization at 84 Ma while hornblende from the central part yields a cooling age of $76 \mathrm{Ma}$. Crawford et al. (1987) interpret the Prince Rupert shear zone as a westdirected thrust with the Ecstall pluton in the upper plate (Fig. 3). For the central part of the pluton, paleomagnetic directions are concordant with the expected Cretaceous direction while observed directions from the western margin are discordant by $>70^{\circ}$. Observed directions are distributed along a small circle with subhorizontal axis at $\sim 340^{\circ}$ azimuth. These directions cannot record northward flight of Baja B.C. because this would require $\sim 7000$ $\mathrm{km}$ of transport in $\sim 8$ m.y. at a velocity of $\sim 1 \mathrm{~m} / \mathrm{yr}$ ! Our tectonic interpretation of the paleomagnetic, geochronologic, and barometric data from the Ecstall 
Figure 2. A: Equal-area projection showing expected Cretaceous direction at location of Spuzzum pluton in southern British Columbia. Directions with inclinations shallower than expected direction occur within blue area; directions with inclinations steeper than expected direction occur within red area. Arrows indicate deflections from expected direction resulting from $20^{\circ}$ tilt of a pluton in directions indicated. O nly a southeast-side-up tilt can yield an inclination steeper than expected direction; all other tilt directions yield shallower inclinations. B: Translation plus rotation interpretation of observed (red square) and expected (green circle) paleomagnetic directions for Spuzzum pluton of southern British Columbia (Irving et al., 1985). O bserved inclination is $17^{\circ}$ shallower than expected inclination and is interpreted to indicate $\sim 2500 \mathrm{~km}$ of northward translation from a Cretaceous location adjacent to southwestern $\mathrm{N}$ orth America. $\mathrm{O}$ bserved declination is clockwise of the expected declination and is interpreted to indicate $58^{\circ}$ of clockwise vertical-axis rotation. C: Tilt interpretation showing deflection of expected direction (green circle) to observed direction (red square) by $30^{\circ}$ northeast-side-up tilt of Spuzzum pluton about a horizontal axis with azimuth $\approx 330^{\circ}$.

pluton involves thrust displacement above the upward convex Prince Rupert shear zone (Fig. 3). We conclude that local folding with $\sim 1000 \mathrm{~km}$ of northward transport produced the paleomagnetic discordance in the Ecstall pluton. These examples show that local folding and tilting are the dominant cause of discordant paleomagnetic directions at least in this part of the Insular terranes and Coast orogen.

\section{THE MODERATE TRAN SLATIO N ALTERNATIVE}

A full synthesis of paleomagnetic data relevant to the Baja B.C. controversy is beyond the scope of this paper. Nevertheless, we provide alternative interpretations of key paleomagnetic studies (Fig. 1) considered by proponents of the Baja B.C. paleogeography to require $\sim 3000 \mathrm{~km}$ post-midCretaceous northward transport (Irving et al., 1996; Cowan et al., 1997). Our alternative interpretation is consistent with the suggestion that the combined effects of $\sim 1000 \mathrm{~km}$ northward translation with tilting of crustal panels about axes parallel to the Coast orogen and compaction shallowing of paleomagnetic inclination in sedimentary rocks can explain the paleomagnetic observations. Note that we do not reject any paleomagnetic data. Instead, we offer alternative interpretations of these important observations.

Bogue et al. (1995) reported a paleolatitude based on paleomagnetic results from the mid-Cretaceous layered ultramafic intrusion of Duke Island in southeast Alaska. They argued that unplunging of fold axes followed by unfolding could restore cumulate layering and paleomagnetic vectors to paleohorizontal. We recently obtained paleomagnetic directions from sites where the attitude of cumulate layering was directly measured (Butler et al., 2001a). These data fail a fold test and indicate that cumulate layering was highly contorted at the time of magnetization. Observations of cumulate layering in other ultramafic intrusions indicate that layering can depart from horizontal by $10^{\circ}-20^{\circ}$, even on the kilometer scale (Irvine et al., 1998). We conclude that use of such cumulate layering as a proxy for paleohorizontal is not justified and paleomagnetic data from Duke Island cannot be used to infer a Cretaceous paleolatitude for the Insular terranes.

Based on paleomagnetic data from only 20 specimens of sedimentary rock from the Upper Cretaceous MacColl Ridge Formation in the southern Alaska fragment of the Wrangellia terrane (Fig. 1), Panuska (1985) reported a paleolatitude of $32^{\circ} \mathrm{N}$. This result suggested a dramatic $4000 \mathrm{~km}$ of postCretaceous northward transport. However, Trop et al. (1999) resampled the MacColl Ridge Formation, concentrating on volcanic tuff layers, and arrived at a much-reduced estimate of displacement. The data from 15 sites (129 samples) yield an inferred Late Cretaceous paleolatitude of $53^{\circ} \mathrm{N} \pm 8^{\circ}$, indicating $1650 \pm 1100 \mathrm{~km}$ of northward displacement.

The paleomagnetic results from the Cenomanian to Campanian Silverquick Conglomerate and the Powell Creek volcanic rocks in the Tyaughton Basin were interpreted by Wynne et al. (1995) to require $3000 \mathrm{~km}$ of northward translation. The conflict of this interpretation with geological correlations and estimates of offset between the Methow and Tyaughton basins has been described by Monger and Price (1996). In the Silverquick-Powell Creek sequence, there is evidence for authigenic magnetite in the sedimentary rocks, suggesting the magnetization could be of secondary chemical origin. Indeed, the maximum clustering of paleomagnetic 
directions occurs at $70 \%$ unfolding. Further, considering the evidence for remagnetization of equivalent rocks in the Methow Basin (Bazard et al., 1990), we conclude that the Silverquick-Powell Creek strata contain a synfolding remagnetization which cannot be used to infer its motion history. Recently, Haskin et al. (2000) obtained paleomagnetic data from $104 \mathrm{Ma}$ volcanic rocks that unconformably underlie the Silverquick Conglomerate and Powell Creek volcanics. The mean paleomagnetic direction is indistinguishable from that of the correlative Spences Bridge Group (Irving et al., 1995), and the combined results provide a strong indication that this assemblage was $1100 \pm 600 \mathrm{~km}$ south at 104 Ma.

The paleomagnetic direction from the Mount Stuart batholith is discordant, again with shallow inclination and clockwise declination compared with the expected Cretaceous direction (Beck et al., 1981). Butler et al. (1989) argued that southwest dipping sedimentary rocks of the Swauk Formation adjacent to the southwestern part of the batholith require post-early Eocene northeastside-up tilt which largely explains the discordant paleomagnetism. However, that interpretation was challenged by Miller et al. (1990). Ague and Brandon (1996) applied aluminum-inhomblende barometry to infer a tilt of $8^{\circ}$ northwest-side-up. Anderson (1997) criticized the pressure estimates of Ague and Brandon (1996), concluding that their pressure estimates are not reliable. That conclusion was, in turn, refuted by Ague and Brandon (1997). Perhaps the most secure conclusion to reach about the Mount Stuart batholith is that the postmagnetization history of deformation is disputed and complex.

Paleomagnetic data from marine sedimentary rocks of the Upper Cretaceous Nanaimo Group have been interpreted by Ward et al. (1997) to support the Baja B.C. model. However, the clay content of the Nanaimo sedimentary rocks likely made them susceptible to inclination shallowing by burial compaction. Laboratory experiments with synthetic and natural clay-rich sediments indicate that detrital Fe-oxide particles become attached to clay particles and rotate toward the horizontal during fabric development accompanying compaction, thus shallowing the inclination (Sun and Kodama, 1992). The remanence anisotropy of paleomagnetic samples can be used to correct for inclination shallowing caused by compaction (Kodama, 1997). Kim and Kodama (1999) showed that Nanaimo rocks, including some of the calcite concretions sampled for paleomagnetism, have a magnetic fabric characteristic of burial compaction, indicating $\sim 15^{\circ}$ of inclination shallowing. Correcting for the effects of compaction reduces the latitudinal displacement by $1500 \mathrm{~km}$ indicating that the Nanaimo rocks were slightly south of the Intermontane terranes in Late Cretaceous time.

The above discussion presented viable alternatives to the Baja B.C. paleogeography for interpreting the paleomagnetic observations. In some cases, these "tilt plus moderate translation" interpretations are well supported by the geology. In other cases, this explanation is speculative and requires further study. Housen and Beck (1999) argued that tilting of Cretaceous plutonic rocks, compaction of Cretaceous sedimentary rocks, and synfolding remagnetization of
Cretaceous volcanic rocks could never conspire to produce the shallow observed paleomagnetic inclinations from the Insular terranes and Coast Mountains. If these processes resulted in both steeper and shallower inclinations with equal probabilities, we would agree with their assessment. But compaction of sedimentary rocks will shallow paleomagnetic inclinations, tilting of the plutonic rocks strongly favors shallowed inclinations, and the same bias affects rocks that experience tilting or folding subsequent to remagnetization.

It is worth recalling that early conclusions of $2500 \mathrm{~km}$ northward transport for coastal and Baja California were based on paleomagnetic data from a half dozen Mesozoic and Cenozoic formations. When about 20 studies had been published, the implied motion histories became complex with internal inconsistencies begging alternative explanation. Dickinson and Butler (1998) concluded that Neogene offset on the San Andreas fault system is sufficient to account for the paleomagnetic data, when compaction shallowing in sedimentary rocks and tilting of plutonic rocks are taken into account. Might history repeat in the case of the Baja B.C. hypothesis once

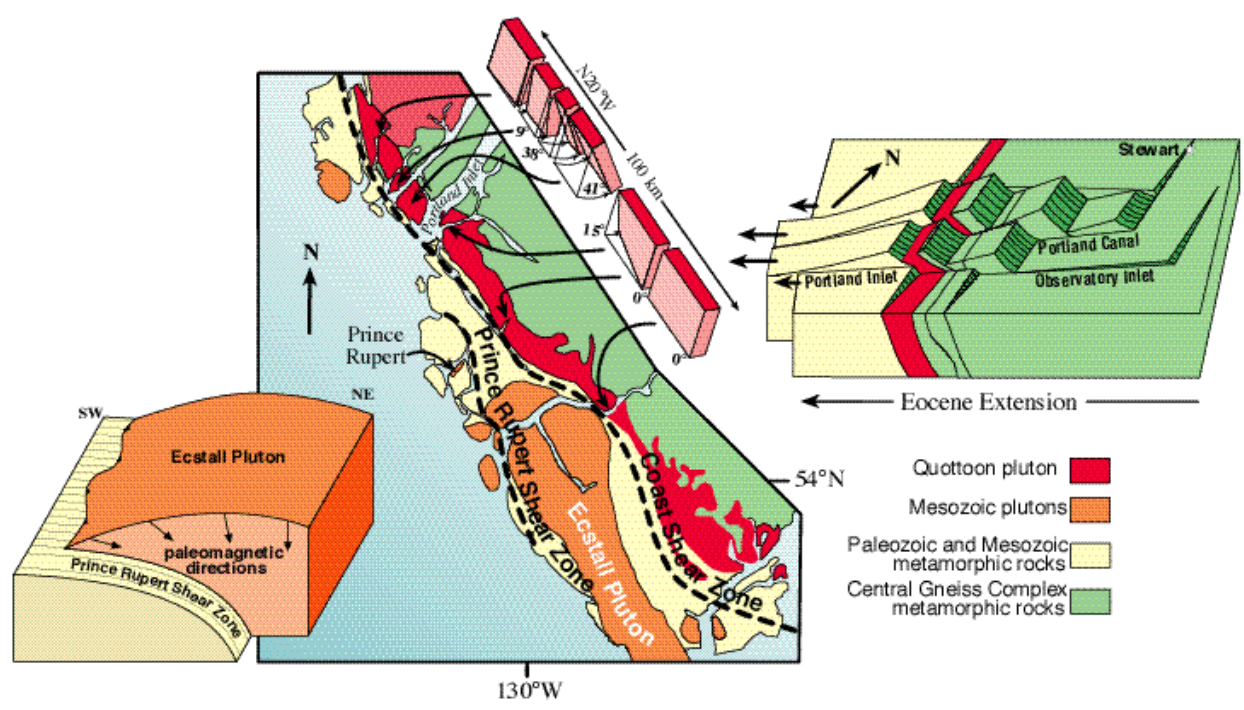

Figure 3. Summary of paleomagnetic observations of tilting and folding of plutonic rocks in Prince Rupert area. Diagram at upper right shows along-strike variation in amount of northeast-side-up tilt that affected Q uottoon plutonic complex. Illustration at right is tectonic model for tilting of crustal panels containing Q uottoon plutonic complex during Eocene extension. Folding model for Ecstall pluton is shown by block diagram at left with arrows indicating paleomagnetic directions. Ecstall pluton is shown above west vergent and convex upward Prince Rupert shear zone. View is toward north. Geologic map is from Hutchison (1982) while geologic structures are adapted from Crawford et al. (1987). 
additional paleomagnetic data and a supporting array of geologic observations are acquired?

\section{TO WARDS A MID-CRETACEO US PALEO G EO G RAPHY}

Reinterpretation of paleomagnetic data from Insular and Intermontane terranes allows for the construction of a simplified Late Cretaceous paleogeographic map of western North America that is consistent with both geologic relations and with conservative estimates of displacement based on paleomagnetism (Fig. 4). The likely positions of Cordilleran terranes, magmatic belts, and first-order strike-slip fault systems at $\sim 90$ Ma differ significantly from the "Northern Option" reconstruction of Cowan et al. (1997). We incorporate $\sim 1000 \mathrm{~km}$ of northward translation of Insular terranes and $\sim 800$ $\mathrm{km}$ of northward motion of Intermontane terranes, most of which occurred during Late Cretaceous through Eocene time. These transport values are generally at the low end of the translation estimates based on paleomagnetic studies from the Insular and Intermontane terranes. An appealing aspect of this reconstruction is the existence of a continuous, subduction-related magmatic arc along the Cordilleran margin.

The inboard strike-slip fault (Fig. 4) is interpreted to include a broad zone of structures related to the Tintina-Rocky Mountain trench system in the northern Cordillera, and their cryptic continuations into southern British Columbia and northern Washington (Gabrielse, 1985). The fault shown between Insular and Intermontane terranes is interpreted to have $\sim 200 \mathrm{~km}$ of dextral slip. Expressions of this structure would include the Denali fault in Alaska (north of the intersection with the Chatham Strait fault), the Coast shear zone and related structures within the Coast Mountains (Lanphere, 1978; Hollister and Andronicos, 1997) and the Yalakom, Harrison Lake, and related faults in southern British Columbia and northem Washington (Umhoefer and Schiarizza, 1996).

If we are relieved of the necessity to move Baja B.C. $3000 \mathrm{~km}$ north during the Late Cretaceous and Paleogene, some aspects of plate kinematics and North American continental dynamics

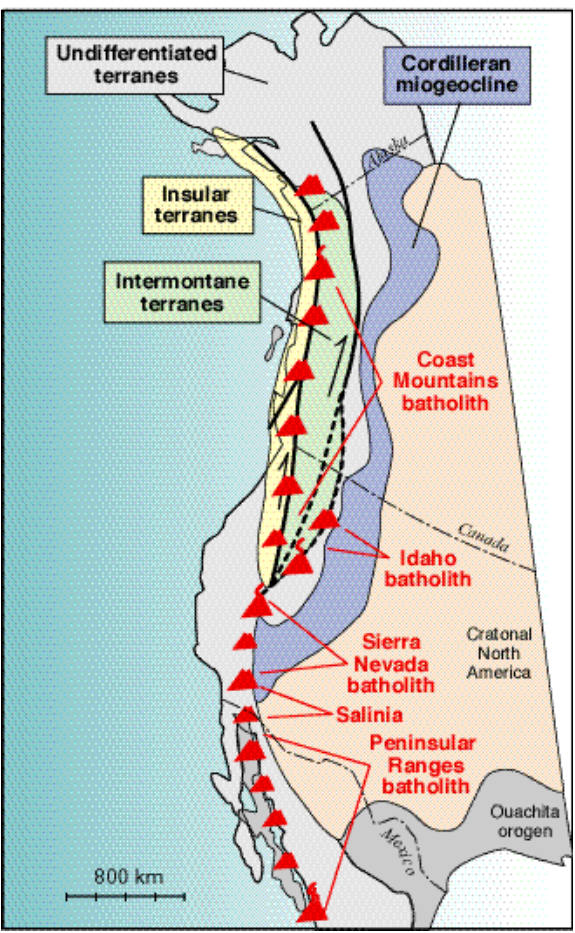

Figure 4. Generalized paleogeography of western $\mathrm{N}$ orth America at $\sim 90 \mathrm{Ma}$, based on geologic relations and the reinterpreted paleomagnetic data (adapted from O Idow et al., 1989; Burchfiel et al., 1992; Plafker and Berg 1994; and Nokleberg et al., 1998). Restorations include $325 \mathrm{~km}$ of Basin and Range province extension, $500 \mathrm{~km}$ northward motion of Salinia, $300 \mathrm{~km}$ opening and offset in Gulf of California, 800 km offset on Tintina-Rocky Mountain Trench fault system and possible continuations to the south, and $200 \mathrm{~km}$ offset on Coast shear zone and related structures and their possible continuations. Known and inferred trace of main locus of subduction-related magmatism is represented by red "volcanoes."

are more easily understood. Dickinson and Snyder (1978) suggested that onset of flat subduction of the Farallon plate under North America could explain the inland migration of magmatism and foreland deformation during the Laramide orogeny which commenced at $75 \mathrm{Ma}$. Geodynamic models confirm that basal traction from flat slab subduction is required to account for foreland deformation far inboard from the continental margin (Bird, 1998). Models depending on interactions at the subduction margin, such as the hit-and-run collision of Baja B.C. with the southwestern margin (Maxson and Tikoff, 1996), cannot transmit compressional forces sufficiently far inboard.

Proponents of the Baja B.C. model have often appealed to the southem option for the Kula-Farallon ridge (Engebretson et al., 1985) so that Baja B.C. could be moved northward on the Kula plate. Instead, the northeast direction of foreland shortening south of $49^{\circ} \mathrm{N}$ between 75 and $50 \mathrm{Ma}$ and the contrast with Rocky Mountain deformation closer to the continental margin farther north is readily understood using the simpler northern option for the Kula-Farallon ridge. Indeed, the northern option is strongly favored by seismic tomography of the subducted Kula-Farallon plate boundary, which is imaged under the Great Lakes region (Bunge and Grand, 2000).

\section{CONCLUSIONS}

The Baja B.C. controversy is primarily the result of sparse and piecewise application of paleomagnetism and supporting geologic and geochemical methods to an orogen which experienced complex deformation and from which supracrustal rocks have largely been removed. The above analysis suggests that discordant paleomagnetic directions from the Cordilleran margin of North America are understandable within a paleogeography which limits post-mid-Cretaceous northward motion to $\sim 1000 \mathrm{~km}$. A necessary condition for embracing this smaller amount of latitudinal motion, as opposed to the $\sim 3000 \mathrm{~km}$ displacements of the Baja B.C. hypothesis, is recognition that crustal panels of the Insular terranes and Coast orogen have experienced tilting or folding around axes subparallel to the continental margin. Dense paleomagnetic sampling along with $\mathrm{U}-\mathrm{Pb}$ geochronology, ${ }^{40} \mathrm{Ar} /{ }^{39} \mathrm{Ar}$ thermochronology, geobarometric analyses, and structural geology have established that such tilting and folding has affected the margin near Prince Rupert, British Columbia. The utility of paleomagnetism in deciphering the tectonics of midcrustal rocks in extensional settings has been documented in the Omineca belt of southeast British Columbia (Wingate and Irving, 1994) and in the Basin and Range (Livaccari et al., 1995). These successful applications are traceable in part to tighter constraints on interpretation because large transport of these areas is not an option. We expect 
that resolution of the Baja B.C. controversy through wider application of interdisciplinary approaches will usher in a period of rapid advance in understanding of the northern Cordillera. Coordinated with the increasing array of sophisticated geological and geochemical methods applicable to elucidating crustal architecture, paleomagnetism will play a central role.

\section{ACKN O WLED G MEN TS}

We thank Bill Dickinson for stimulating discussions and Kathleen Koopman for assistance with figures. The manuscript was improved by careful reviews from David Evans, John Geissman, Paul Umhoefer, and Karl Karlstrom. Funding was provided by the Tectonics Program of the National Science Foundation.

\section{REFEREN CES CITED}

Ague, J.J., and Brandon, M.T., 1996, Regional tilt of the M ount Stuart batholith, Washington, determined using aluminum in hornblende baro metry: Implications for northward translation of Baja British Columbia: G eological Society of America Bulletin, v. 108, p. 471-488.

Ague, J.J., and Brandon, M.T., 1997, Regional tilt of the M ount Stuart batholith, Washington, determined using aluminum-in-hornblende barometry: Implications for northward translation of Baja British Columbia: D iscussion: Geological Society of America Bulletin, v. 109, p. $1225-1227$

Anderson, J.L., 1997, Regional tilt of the Mount Stuart batholith, Washington, determined using aluminum-inhornblende barometry: Implications for northward translation of Baja British Columbia: Discussion: Geological Society of America Bulletin, v. 109, p. 1223-1225.

Bazard, D.R., Burmester, R.F., Beck, M.E. Jr., Granirer, J.L., and Schwarz, C.G., 1990, Paleomagnetism of the Methow region, north-central Washington: Structural application of paleomagnetic data in a complexly deformed, variably remagnetized terrane: Canadian Journal of Earth Science, v. 27, p. 330-343.

Beck, M.E., 1980, Paleomagnetic record of plate-margin tectonics processes along the western edge of North America: Journal of Geophysical Research B: Solid Earth, v. 85, p. $7115-7131$.

Beck, M.E. Jr., Burmester, R.F., and Schoonover, R., 1981, Paleomagnetism and tectonics of Cretaceous Mount Stuart batholith of Washington: Translation or tilt?: Earth and Planetary Science Letters, v. 56, p. 336-342.

Beck, M.E. Jr., Burmester, R.F., Craig, D.E., Grommé, C.S. and Wells, R.E., 1986, Paleomagnetism of middle Tertiary volcanic rocks from the W estern Cascade series, northern California: Timing and scale of rotation in the southern Cascades and Klamath Mountains: Journal of Geophysical Research, v. 91, p. 8219-8230.

Bird, P., 1998, Kinematic history of the Laramide orogeny in latitudes $35^{\circ}-49^{\circ} \mathrm{N}$, w estern U nited States: Tectonics, v. 17, p. $780-801$.

Bogue, S.W., Grommé, S., and Hillhouse, J.W., 1995, Paleomagnetism, magnetic anisotropy, and mid-Cretaceous paleolatitude of the Duke Island (Alaska) ultramafic complex: Tectonics, v. 14, p. 1133-1152.

Brown, E.H., and Burmester, R.F., 1991, M etamorphic evidence for tilt of the Spuzzum pluton: Diminished basis for the "Baja British Columbia" concept: Tectonics, v. 10, p. $978-985$

Bunge, H.-P., and Grand, S.P., 2000, Mesozoic platemotion history below the northeast Pacific $\mathrm{O}$ cean from seismic images of the subducted Farallon slab: Nature, v. 405, p. $337-340$

Burchfiel, B.C., Cowan, D.S., and Davis, G.A., 1992, Tectonic overview of the Cordilleran orogen in the western U nited States, in Burchfiel, B.C., et al., eds., The Geology of N orth America: The Cordilleran orogen: Conterminous U.S.: Boulder, Colorado, USA, Geological Society of America, p. 407-480.

Butler, R.F., Gehrels, G.E., and Hart, W., 2000, Paleomagnetism of plutonic rocks near Prince Rupert, British Columbia: Importance of tilting and folding, Geological Society of America Abstracts with Programs, v. 23 , no. 7, p. A245.

Butler, R.F., Gehrels, G.E., and Saleeby, J.B., 2001a, Paleomagnetism of the Duke Island (Alaska) ultramafic complex revisited: Journal of Geophysical Research (in press).

Butler, R.F., Gehrels, G.E., Crawford, M.L., and Crawford, W.A., 2001b, Paleomagnetism of the $Q$ uottoon plutonic complex in the Coast M ountains of British Columbia and southeastern Alaska: Evidence for tilting during uplift: Canadian Journal of Earth Science (in press).

Butler, R.F., Gehrels, G.E., M cClelland, W.C., M ay, S.R., and Klepacki, D., 1989, Discordant paleomagnetic poles from the Canadian Coast Plutonic Complex: Regional tilt rather than large-scale displacement?: Geology, v. 17, p. 691-694.

Coney, P.J., Jones, D.L., and M onger, J.W.H., 1980, Cordilleran suspect terranes: N ature, v. 288, p. 329-333.

Cowan, D.S., Brandon, M.T., and Garver, J.L., 1997, Geologic tests of hypotheses for large coastwise displacements-A critique illustrated by the Baja British Columbia controversy: American Journal of Science, v. 297, p. 117-173.

Crawford, M.L., Hollister, L.S., and W oodsworth, G.J., 1987, Crustal deformation and regional metamorphism across a terrane boundary, Coast Plutonic Complex, British Columbia: Tectonics, v. 6, p. 343-361.

Dickinson, W.R., and Butler, R.F., 1998, Coastal and Baja California paleomagnetism reconsidered: Geological Society of America Bulletin, v. 110, p. 1268-1280.

Dickinson, W.R., and Snyder, W.S., 1978, Plate tectonics of the Laramide orogeny, in Matthews, I.V., ed., Laramide folding associated with basement block faulting in the westem United States: Boulder, Colorado, USA, G eological Society of America Memoir 151, p. 355-366.

Engebretson, D.C., Cox, A., and Gordon, R., 1985, Relative motions between oceanic and continental plates in the Pacific basin: Boulder, Colorado, USA, Geological Society of America Special Paper 206, p. 1-59.

Gabrielse, H., 1985, Major dextral transcurrent displacements along the N orthern Rocky M ountain Trench and related lineaments in north-central British Columbia: Geological Society of America Bulletin, v. 96, p. 1-14.

Gehrels, G.E., and Kapp, P.A., 1998, Detrital geochronology and regional correlation of metasedimentary rocks in the Coast Mountains, southeastern Alaska: Canadian Journal of Earth Science, v. 35, p. 269-279.

H askin, M.L., M ustard, P.S., M ahoney, J.B., Enkin, R.J., and Friedman, R., 2000, Multidisciplinary correlation of midCretaceous volcanic packages across the Insular/ Intermontane superterrane boundary: Implications for the Baja B.C. hypothesis: Geological Society of America Abstracts with Programs, v. 32, no. 7, p. A107-A108.

Hess, H.H., 1962, History of ocean basins, in Engel, A.E.J., et al., eds., Petrological studies: A volume in honor of A.F. Buddington: Boulder, Colorado, USA, Geological Society of America, p. 599-620.

Hillhouse, J.W., 1977, Paleomagnetism of the Triassic Nikolai G reenstone, M cCarthy quadrangle, Alaska: Canadian Journal of Earth Science, v. 14, p. 2578-2592.

Hollister, L.S., and Andronicos, C.L., 1997, A candidate for the Baja British Columbia fault system in the Coast Plutonic Complex: GSA Today, v. 7, no. 11, p. 1-7.

Housen, B.A., and Beck, M.E. Jr., 1999, Testing terrane transport: An inclusive approach to the Baja B.C. controversy: Geology, v. 27, p. 1143-1146.
Hutchison, W.W., 1982, Geology of the Prince Rupert-Skeena map area, British Columbia, Geological Survey of Canada M emoir 394, 116 p.

Invine, T.N., Anderson, J.C.Ø., and Brooks, C.K., 1998, Included blocks (and blocks within blocks) in the Skaergaard intrusion: Geologic relations and the origins of rhythmic modally graded layers: Geological Society of America Bulletin, v. 110, p. 1398-1447.

Irving, E., 1988, The paleomagnetic confirmation of continental drift: Eos (Transactions, American Geophysical Union), v. 69, p. 1001-1014.

Irving, E., Thorkelson, D.J., Wheadon, P.M., and Enkin, R.J., 1995, Paleomagnetism of the Spences Bridge Group and northward displacement of the Intermontane Belt, British Columbia: A second look: Journal of $G$ eophysical Research, v. 100 , p. 6057-6071.

Irving, E., W oodsworth, G.J., Wynne, P.J., and M orrison, A., 1985, Paleomagnetic evidence for displacement from the south of the Coast Plutonic Complex, British Columbia: Canadian Journal of Earth Science, v. 22, p. 584-598.

Irving, E., W ynne, P.J., Thorkelson, D.J., and Schiarizza, P., 1996, Large (1000 to $4000 \mathrm{~km}$ ) northward movements of tectonic domains in the northern Cordillera, 83 to $45 \mathrm{M} \mathrm{a:}$ Journal of Geophysical Research, v. 101, p.17,901-17,916. Kamerling, M.J., and Luyendyk, B.P., 1979, Tectonic rotations of the Santa M onica M ountains region, western Transverse Ranges, California, suggested by paleomagnetic vectors: Geological Society of America Bulletin, v. 90, p. 331-337.

Kim, B., and Kodama, K.P., 1999, Magnetic anisotropy of $\mathrm{N}$ anaimo G roup sedimentary rocks from $\mathrm{H}$ ornby Island: Eos (Transactions, American Geophysical U nion), v. 80, p. F299-F300.

Klepeis, K.A., Crawford, M.L., and Gehrels, G.E., 1998 Structural history of the crustal-scale Coast shear zone near Portland Inlet, southeast Alaska and British Columbia: Journal of Structural Geology, v. 20, p. 883-904.

Kodama, K.P., 1997, A successful rock magnetic technique for correcting paleomagnetic inclination shallowing: Case study of the Nacimiento Formation, N ew M exico: Journal of Geophysical Research, v. 102, p. 5193-5205.

Lanphere, M.L., 1978, Displacement history of the Denali fault system, Alaska and Canada: Canadian Journal of Earth Science, v. 15, p. 817-822.

Livaccari, R.F., Geissman, J.W., and Reynolds, S.J., 1995 , Large-magnitude extensional deformation in the South M ountains metamorphic core complex, Arizona: Evaluation with paleomagnetism: Geological Society of America Bulletin, v. 107, p. 877-894.

Mahoney, J.B., Tikoff, B., Maxson, J., and H augerud, R.A., 2000 , Terrane accretion along the western Cordilleran margin: Constraints on timing and displacement: GSA Today, v. 10, no. 2, p. 11-13.

Maxson, J., and Tikoff, B., 1996, Hit-and-run model for the Laramide orogeny, western U nited States: Geology, v. 24, p. 968-972.

Miller, R.B., Johnson, S.Y., and M CD ougall, J.W ., 1990, Discordant paleomagnetic poles from the Canadian Coast Plutonic Complex: Regional tilt rather than large displacement?: Comment: Geology, v. 18, p. 1164-1165.

M onger, J.W.H., and Price, R.A., 1996, Paleomagnetism of the Upper Cretaceous strata of Mount Tatlow: Evidence for $3000 \mathrm{~km}$ of northward displacement of the eastern Coast Belt, British Columbia, by P.J. Wynne et al., and Paleomagnetism of the Spences Bridge G roup and northward displacement of the Intermontane Belt, British Columbia: A second look, by E. Irving et al.: Discussion and reply: Journal of Geophysical Research, v. 101, p. 13,79313,800

N okleberg, W.J., Parfenov, L.M., M onger, J.W.H., Norton, I.O., Khanchuk, A.I., Stone, D.B., Scholl, D.W ., and Fujita, K., 1998, Phanerozoic tectonic evolution of the CircumN orth Pacific: U.S. Geological Survey, p. 98-754.

Oldow, J.S., Bally, A.W., Avé Lallemant, H.G., and Leeman, W.P., 1989, Phanerozoic evolution of the North American Cordillera; United States and Canada: Geology of N orth America: Boulder, Colorado, USA, Geological Society of America, p. 139-232. 
Plafker, G., and Berg, H.C., 1994, O verview of the geology and tectonic evolution of Alaska, in Plafker, G., and Berg, H.C., eds., The Geology of Alaska: Geology of N orth America: Boulder, Colorado, USA, Geological Society of America, p. 989-1022.

Price, R.A., and Charmichael, D.M., 1986, Geometric test for Late CretaceousPaleocene intracontinental transform faulting in the Canadian Cordillera: Geology, v. 14, p. $468-471$.

Sun, W.W., and Kodama, K.P., 1992, Magnetic anisotropy, scanning electron microscopy, and $X$-ray pole figure goniometry study of inclination shallowing in a compacting clay-rich sediment: Journal of Geophysical Research, v. 97, p. $19,599-19,615$

Trop, J.M., Stamatakos, J.A., and Ridgway, K.D., 1999, Determining the Late Cretaceous paleolatitude and accretion history of the allochthonous $W$ rangellia Terrane: Paleomagnetism, geochronology, and tectonic analysis of the MacColl Ridge Formation, southern Alaska: Eos (Transactions, American Geophysical U nion), v. 80, p. F948.

U mhoefer, P.J., and Schiarizza, P., 1996, Latest Cretaceous to early Tertiary strike-slip faulting on the southeastern Yalakom fault system, southeastern Coast Belt, British Columbia: Geological Society of America Bulletin, v. 108, p. 768-785.

Vandall, T.A., 1993, Cretaceous Coast Belt paleomagnetic data from the Spetch Creek pluton, B.C.: Evidence for the "tilt and moderate displacement" model: Canadian Journal of Earth Science, v. 30, p. 1037-1048.

Ward, P.D., Hurtado, J.M., Kirschvink, J.L., and Verosub, K.L., 1997, M easurements of the Cretaceous paleolatitude of Vancouver Island: Consistent with the Baja-British Columbia hypothesis: Science, v. 277, p. 1642-1645.

W ingate, M.T.D., and Irving, E., 1994, Extension in high-grade terranes of the so uthern O mineca Belt, British Columbia: Evidence from paleomagnetism: Tectonics, v. 13, p. $686-711$.

W ynne, P.J., Irving, E., Maxson, J.A., and Kleinspehn, K.L., 1995, Paleomagnetism of the U pper Cretaceous strata of M ount Tatlow: Evidence for $3000 \mathrm{~km}$ of northward displacement of the eastern Coast Belt, British Columbia: Journal of Geophysical Research, v. 100, p. 6073-6091.

Manuscript received March 7, 2001; accepted April 9, 2001. A
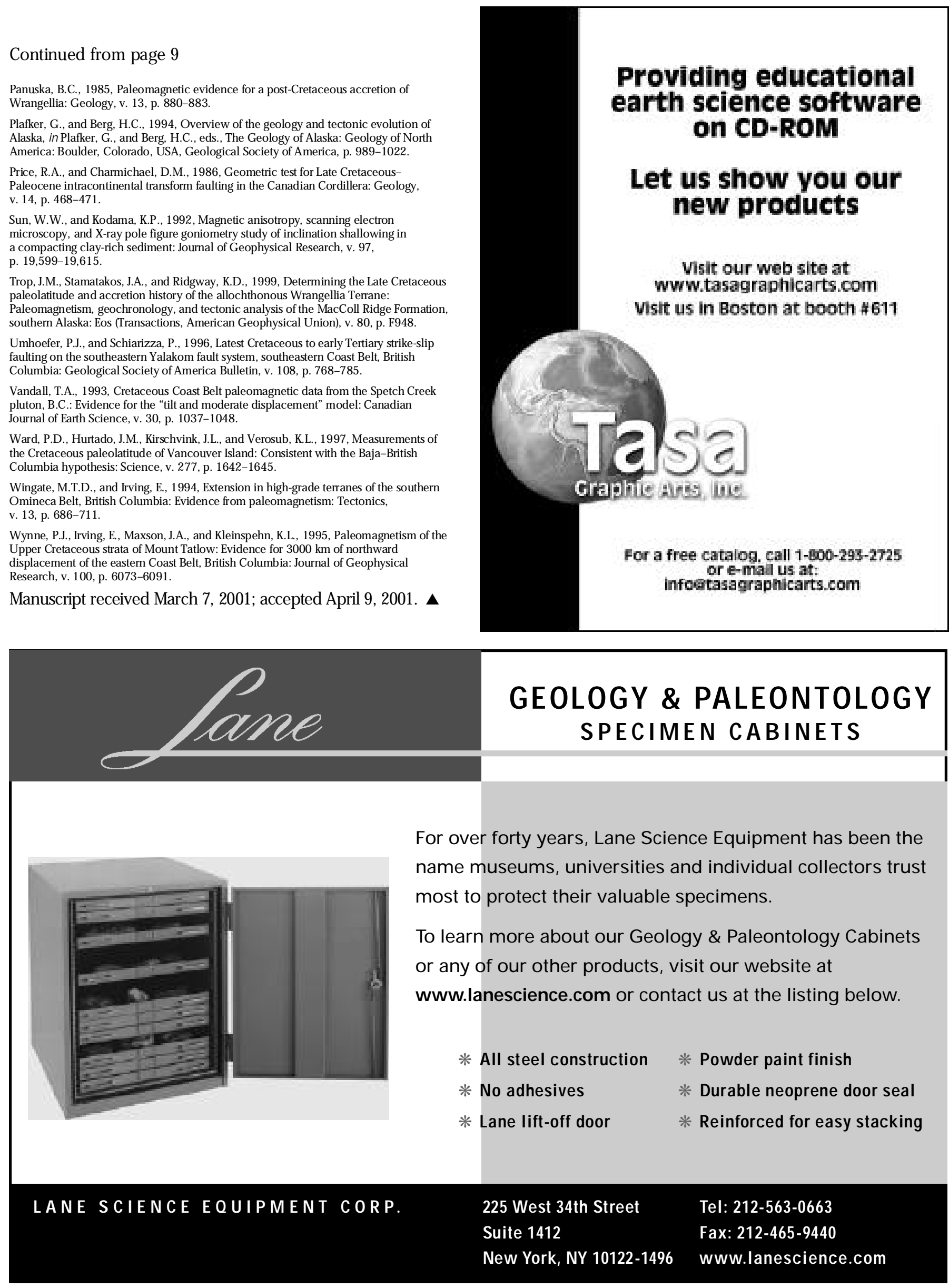